\title{
DETERMINANTS OF SCHOOL ENROLMENT IN INDONESIA: THE ROLE OF MINIMUM WAGE
}

\author{
Dyah S. Pritadrajati \\ Australian National University (ANU), Canberra, Australia, Oxford Poverty and Human \\ Development Initiative (OPHI), Oxford, United Kingdom. \\ Email: dyah.pritadrajati@anu.edu.au / dyah.pritadrajati@gmail.com
}

\begin{abstract}
This paper investigates the role of minimum wages in determining school enrolment (educational investment) in Indonesia using the National Socioeconomic Survey (Susenas). It finds that minimum wage legislation has a negative and significant substitution effect on educational investment. Individuals are more likely to drop out of senior secondary school as a result of a minimum wage legislation. Even though the response among low-income households is positive, this result may be generated by a fall in the probability of obtaining low-skilled employment, which offset the substitution effect.
\end{abstract}

Keywords: Minimum wage; Human capital investment; School enrolment.

JEL Classifications: I25; I28; J24; J48.

Article history:

Received : October 05, 2020

Revised : January 24, 2021

Accepted : March 12, 2021

Available online : June 30, 2021

https://doi.org/10.21098/bemp.v24i2.1484 


\section{INTRODUCTION}

In an effort to improve the living standards of the poor and to reduce inequality, the minimum wage policy has been proposed and implemented not only in developed but also in developing countries. However, the policy has been politically contentious among policymakers and controversial among economists, where the debate on the implications of wage floors persists. Although there has been a growing number of studies on minimum wage, most studies focus predominantly on its employment effects (see Brown et al., 1982; Card and Krueger, 1993; Neumark and Wascher, 2007). In fact, apart from the analysis based on the firm and labour market, households should be considered an important channel for explaining the effect of minimum wage policy, since household behavioural adjustment can generate substantial changes in the economy. In the view that households act as the supplier of labour, a household's decision on educational investment - which affects human capital, and thus the quality of labour supplied-is an essential channel to explain the minimum wage effect.

Neumark and Wascher (1994) find that the effect of minimum wage on employment is sensitive to the introduction of schooling control, highlighting the importance of examining the linkages among minimum wage, employment, and enrolment. Using US state-year observations between 1977 and 1989, Neumark and Wascher (1994) identify a negative influence of minimum wage on school enrolment and a positive influence on the proportion of teenagers neither employed nor in school. This adverse effect of minimum wage on schooling is also confirmed by a series of studies including Chaplin et al. (2003) for the US, Landon (1997) for Canada, Pacheco (2007) for New Zealand, and Rice (2010) for the UK. In contrast, Mattila (1978), using time-series data based on the US Current Population Survey, finds that minimum wage induces enrolment rates. Similarly, Ehrenberg and Marcus (1982) suggest that there is an increase in the educational attainment of white-teens from higher-income families as a response to minimum wage legislation in the US. Cahuc and Michel (1996) also show that minimum wage could positively impact growth by inducing more human capital accumulation, acting as a way of reducing unemployment caused by low demand for unskilled workers.

The limited research that attempts to address the relationship between minimum wage and educational attainment, as well as the lack of universal consensus among previous research, indicates a serious research gap in the literature (Cahuc and Michel, 1996; Chaplin et al., 2003; Ehrenberg and Marcus, 1982; Landon, 1997; Mattila, 1978; Neumark and Wascher, 1994; Pacheco, 2007; Rice, 2010). Moreover, earlier research has some limitations, including the lack of variation in the minimum wage and potential endogeneity bias due to the inability to control for some explanatory variables (see Neumark and Wascher, 1994). Most existing studies were also conducted in developed countries, and only a few studies have been carried out in developing countries (Chaplin et al., 2003; Landon, 1997; Pacheco, 2007; Rice, 2010). To the best of my recollection, there is no previous study investigating the impact of minimum wage legislation on the choice of senior secondary school type, particularly from a developing country's perspective. Therefore, to fill this research gap, this paper investigates the relationship between minimum wage and educational (or human capital) investment-particularly on 
choosing whether or not to attend school, and later the choice of the school type or the employment type - at the individual level, in the Indonesian context.

This paper makes two main contributions to the literature. First, it further investigates the indirect implication of minimum wage by introducing household decisions on educational investment. Second, by using a rich household survey from the National Socio-Economic Survey (Susenas), this paper tries to capture minimum wage effects at the individual level, which may not be detected by statelevel regressions used in most previous research. Furthermore, this paper can be viewed as an effort to analyse whether the minimum wage policy supports or impedes recent Indonesian government efforts to promote school enrolment through its twelve-year compulsory education program ${ }^{1}$. It is worth noting that the government may be unaware of the possible interaction between different policies, especially in a developing country where inter-sectoral policy coordination is very limited.

Indonesia poses as an intriguing case study for analysing the effects of minimum wage for a number of reasons. First, although the first minimum wage legislation introduced in the early 1970s was neither binding nor enforced, the government implemented a new minimum wage legislation in 1989 and started to aggressively promote minimum wage policies as a vital labour policy (Hohberg and Lay, 2015). Second, the minimum wage setting's responsibility is delegated to each of the 34 provincial governments that revise their own minimum wage annually. This reform to the minimum wage, which occurred in 2001, has provided substantial variation in minimum wage data to investigate the impact of the minimum wage policy. Finally, Indonesia's more decentralized political process for the past few years is expected to yield greater variation in regional policies, including those related to the minimum wage (Chun and Khor, 2010).

Because the theoretical predictions on the choice of school enrolment are ambiguous, empirical analysis is, therefore, necessary to untangle the complex theoretical relationship between minimum wage and school choice. This study pursues this objective using a large-scale annual household survey from Susenas as the primary data source. Specifically, using the survey data from 2000 to 2018, I construct a pooled cross-sectional dataset of individuals. The sample includes individuals who completed junior secondary education, and then choose either to attend senior secondary school or to drop out of school. The study utilises a nested logit model with controls for the individual- and household-explanatory variables to capture the possible relationship between minimum wage and choice of school enrolment. I find that the minimum wage legislation has a negative and significant substitution effect on educational investment. That is, individuals are more likely to drop out of senior secondary school as a result of a minimum wage legislation. Despite a positive outcome among low-income households, a regression incorporating an interaction term suggests that the substitution effect is still the dominant factor in explaining the effect of minimum wage.

The rest of this paper is structured as follows. Section II outlines the economic framework underlying the empirical approach, whereas Section III describes the

${ }^{1}$ Government Regulation (PP) No.47/2008 on Compulsory Education: https://peraturan.bpk.go.id/ Home/Details/4861/pp-no-47-tahun-2008 
data and methodology used in the estimations. Section IV contains the analysis and discussion of the effect of an increase in the minimum wage on school enrolment. Finally, Section $\mathrm{V}$ concludes the paper and provides policy recommendations.

\section{A SIMPLE TWO-PERIOD MODEL OF HUMAN CAPITAL INVESTMENT}

The economic framework, which formalises the relationship between minimum wage and choice of school enrolment, is based on a simple two-period model of human capital investment. This model is developed based on Acemoglu and Autor (2000) and Acemoglu and Pischke (2001), which are also inspired by Becker (1964) and Becker and Tomes (1986) theoretical models of investment in human capital.

Consider a household that consists of one adult and one child. In period one, an adult, who lives for just one period, works and earns income $y_{i}$ (either highskilled or minimum wage), consumes $c_{i}{ }^{1}$, and decides whether to invest in his/her child's education $e_{i}$. The total cost-including the opportunity cost-of sending a child to school is $\theta_{i}$, which varies with $i$ as there is heterogeneity among children. Meanwhile, in period two, the child becomes an adult, has a child of his/her own, consumes $c_{i}^{2}$ and earns the wage of a low-skilled worker (minimum wage rate) if he/she did not attend school, $w_{l}$, or the wage of a high-skilled worker if he/she attended school, $w_{h}$.

According to the two-period model set up above, the utility of household $i$ is given as:

$$
U=\ln c_{i}^{1}+\beta \ln c_{i}^{2}
$$

where $\beta$ is a parameter that measures how important future (child's) consumption is to current consumption. Following the 'separation theorem' for human capital investment, the decision on school enrolment will be made simply to maximise the budget set of the household; hence, $e_{i}$ does not appear in the objective function. In the case of a perfect capital market in which the adult can borrow for his/her child with an interest rate $r$, the decision problem of the adult is therefore to maximise household utility subject to the household budget constraint, which is given as:

$$
c_{i}^{1}+\frac{c_{i}^{2}}{(1+r)} \leq y_{i}-e_{i} \theta_{i}+\frac{w_{l}}{(1+r)}+e_{i} \frac{w_{h}-w_{l}}{(1+r)}
$$

For an adult to send his/her child to school and to invest in his/her education, the following equation must be satisfied:

$$
\theta_{i} \leq \frac{w_{h}-w_{l}}{(1+r)}
$$

which asserts that the cost of schooling $\theta_{i}$ must be less than or equal to the net present value of the skill premium $w_{h}-w_{l}$ obtained from enrolling at school. 
For this solution to hold, it should be noted, strong assumptions including a fully altruistic parent (the parent is willing to borrow to finance the child's education or $\beta=1$ ) and the absence of credit market problems (such as informational/ contractual problems) are required. However, in practice, credit market problems are prevalent, especially in the context of a developing country. In Indonesia, Johnston and Morduch (2008) find that, out of 40 percent of creditworthy poor households, only 10 percent recently borrowed from a traditional bank, suggesting a large gap between financial use and creditworthiness. In that case, it is important to take into account the credit market problems in the model setup. In this scenario, it is assumed that the adult is either unable or unwilling to borrow. Thus, saving cannot be negative or to simplify, saving is zero in both periods. This modifies the budget set as follows:

$$
\begin{aligned}
& c_{i}^{1}=y_{i}-e_{i} \theta_{i} \\
& c_{i}^{2}=w_{l}+e_{i}\left(w_{h}-w_{l}\right)
\end{aligned}
$$

Furthermore, the utilities from sending and not sending the child to a school are given, respectively, by:

$$
\begin{aligned}
& U\left(e_{i}=1 \mid y_{i}, \theta_{i}\right)=\ln \left(y_{i}-\theta_{i}\right)+\ln w_{h} \\
& U\left(e_{i}=0 \mid y_{i}, \theta_{i}\right)=\ln y_{i}+\ln w_{l}
\end{aligned}
$$

Hence, an adult will send his/her child to school if the following condition is satisfied:

$$
\begin{aligned}
& \ln \left(y_{i}-\theta_{i}\right)+\ln w_{h} \geq \ln y_{i}+\ln w_{l} \\
& y_{i} \frac{w_{h}-w_{l}}{w_{h}} \geq \theta_{i}
\end{aligned}
$$

Besides the household's optimality specified in Equation (7), another constraint on school enrolment decision is the condition that household income in each period cannot be less than the minimum subsistence level (Wongsangaroonsri, 2016). The arbitrary minimum basket of consumption for a household is $\bar{c}_{i^{\prime}}$ which varies across households, to consider household-specific consumption preference. It is assumed that $w_{l} \geq \bar{c}_{i}$ and without access to the credit market, the household that earns income at the minimum wage level is bound to this additional constraint:

$$
\bar{c}_{i}+\theta_{i} \geq w_{l}
$$

As a response to an increase in the minimum wage, conditions (7) and (8) generate two opposing impacts on the choice of senior secondary school type. According to Equation (7), a higher level of minimum wage decreases the skill premium because it increases the wage of the low-skilled worker. As a result, the minimum wage legislation reduces the net benefit of sending a child to a school 
and induces a child to drop out of school (substitution effect). On the other hand, an increase in the minimum wage causes the income constraint in condition (8) to become less binding; hence, the child will be more likely to enrol at school (income effect). In addition to the direct impact of minimum wage on wage (supply side), the school choice decision is also influenced by the indirect impact of minimum wage on employment probability. This impact also consists of two conflicting forces, depending on the labour market structure (demand side). Under the competitive labour market, the substitution of low-skilled for the high-skilled workers-due to an increase in the minimum wage-will increase the net benefit of investing in human capital and give rise to students' enrolment at school. Meanwhile, in the monopsonistic labour market, the higher probability of getting a job reduces the incentive to invest further in education, thus inducing students to drop out of school.

Therefore, the total effect of an increase in minimum wage will depend on the combination of its impact on wage and employment probability. For example, if the substitution effect of the minimum wage is offset by a fall in the probability of obtaining low-skilled employment, the child will be more likely to enrol at school. Conversely, suppose the adverse effect on employment is small or the probability of employment increases. In that case, the increase in the minimum wage will raise the opportunity cost of going to school, and the child will be more likely to drop out of school.

\section{DATA AND METHODOLOGY}

A. Data Characteristics

A large-scale annual household survey from Susenas, covering approximately 300,000 households in Indonesia's 34 provinces, serves as the primary data source for this paper. It contains a core questionnaire consisting of a household roster listing the sex, age, marital status, and the educational attainment of all household members. The survey is supplemented by modules covering additional information such as health care and nutrition, household income and expenditure, and labour force experience. Meanwhile, the macroeconomic variables, including the provincial nominal minimum wage, Gross Domestic Product (GDP) price deflator, and poverty line, are obtained from the Indonesian Bureau of Statistics. The provincial real minimum wage variable is created by dividing the provincial nominal minimum wage with provincial GDP price deflator in each year to index the variable in terms of 2010 rupiah. Besides, the household expenditure is adjusted spatially and temporally by multiplying the nominal household expenditure with the average national poverty line in the base year, and then dividing the result by the provincial poverty line.

Using the survey data from 2000 to 2018, I construct a pooled cross-sectional dataset of individuals. Our sample includes individuals who completed junior secondary education, and then choose either to attend senior secondary education or to drop out of school. Starting from 2015, the Indonesian government implemented the twelve-year compulsory education program, which was nine-year in the previous years. However, this program's take-up is still meagre; the drop-out rate at junior secondary school is still the highest compared to other educational 
levels (for instance, 51,200 students dropped out in 2017/2018 as reported by the Ministry of National Education and Culture ${ }^{2}$. Therefore, it is assumed that the schooling choice is made when students completed junior secondary school. In addition, the sample chosen for this study is individuals at the age of 15 to 21 during the survey year, as these are the times when students are enrolled in senior secondary school. The choice of the lower age cut-off is in line with the definition of the working-age population, in which it is defined as those aged from 15 to 64 according to the Indonesia's Central Bureau of Statistics. Meanwhile, the upper age cut-off is in accordance with the Regulation of the Minister of Education and Culture (Permendikbud) No.44/2019 Article $7^{3}$, stating that one of the requirements for new student candidates for grade 10 senior secondary school high school is that candidates have to be at the maximum age of 21 years on July 1 of the particular academic year. To avoid endogeneity, individuals who migrated across the province are not included in the analysis as the migration might be motivated by incentives to pursue a higher minimum wage.

The dependent variable of this study is the choice of human capital investment after completing junior secondary school, which is categorised into two choice types: to attend senior secondary school or to drop out of school. Under the subset of "attending senior secondary school", there are two choices: attending general or vocational senior secondary. Individuals attending general senior secondary schools are those enrolled in Sekolah Menengah Atas (SMA) and Madrasah Aliyah (MA), equivalent to general senior secondary school but under the Ministry of Religion's management. Meanwhile, individuals attending vocational senior secondary schools are those enrolled in Sekolah Menengah Kejuruan (SMK) and Madrasah Aliyah Kejuruan (MAK). On the other hand, within the subset of "dropping out of school", there are two alternatives: work at a formal sector or not at a formal sector. Individuals categorised with formal employment are self-employed with unpaid family or temporary workers in the non-agricultural industry, self-employed with permanent workers, government and private-sector workers. Meanwhile, individuals categorised with non-formal employment are those working in the informal sector (self-employed, unpaid family workers, selfemployed with unpaid or temporary workers in the agricultural industry, and casual workers), taking care of the household, and doing other activities besides personal routines.

The variable of interest is the log value of the annual real minimum wage, set at the provincial level. Some control variables included in the analysis are gender, age, marital status, and urban residency dummy. Household-level control variables in the analysis are mother's and father's highest educational attainment, household size, number of children in the household disaggregated based on age (1-5, 5-15, and above 15 years old), and the log value of real monthly household expenditure, disaggregated into food and non-food expenditures. To ensure the comparability of real monthly household expenditure variable across different family sizes, the value is divided by $\sqrt{n}$ in the sense that the marginal cost of living

\footnotetext{
2 Indonesia educational statistics: http://statistik.data.kemdikbud.go.id/

3 Permendikbud No.44/2019: https://jdih.kemdikbud.go.id/arsip/Permendikbud\%20Nomor\%2044\%20 Tahun\%202019.pdf
} 
is decreasing as the number of household members is increasing. Moreover, to reflect employment availability in the labour market, the estimation also controls for provincial level unemployment rate. These control variables at the individual and household levels are the case-specific variables for the first decision level in the nested logit model use in this study. Equally important, the share of each alternative at the district level poses as the alternative-specific variable, which varies among the bottom-level alternatives, the four choices that one could make after completing junior secondary school.

As information about senior secondary school choice is only observed once during a person's lifetime (unless the student has to repeat grade and transfer to another school), a panel dataset cannot be constructed, and a fixed effects model at the individual level cannot be used for the analysis. Besides, to the best of my knowledge, a plausible instrument for minimum wage is not available. Therefore, to limit potential sources of endogeneity in the regression due to omitted variables, it is crucial to control for as many predetermined or exogenous characteristics as possible. Despite these limitations, compared to pure cross-sectional and timeseries data, the independently pooled cross-sectional data offers some advantages, including more precise estimators due to the availability of more observations and the ability to trace the evolution of the dependent variable over time after controlling for confounders. Moreover, as the data is collected independently of each other across clusters, serial correlation of residuals is not an issue when applying the regression analysis.

\section{B. Methodology}

A nested logit model with controls for the individual- and household-explanatory variables to capture the possible relationship between minimum wage and choice of school enrolment is utilised for the analysis. This nested logit model allows for a non-zero correlation between unobserved components of choices within a nest and maintains zero correlation across nests (Heiss, 2002). Hence, this model relaxes the assumption of independently distributed errors and the Independence of Irrelevant Alternatives (IIA), which implies proportional substitution across alternatives, inherent in conditional and multinomial logit models by clustering similar alternatives into nests (Train, 2009). In this paper, an individual's choices after completing Junior Secondary School (JSS) are grouped by choice type: to attend Senior Secondary School (SSS) or to drop out of school. The tree structure of an individual's decision about what he/she wants to do after completing junior secondary school is presented in Figure 1. The tree diagram consists of two branches, labelled "Attend SSS" and "Drop out", for the two subsets of alternatives, and each of the branches contains two twigs for the two alternatives within the subset. There is proportional substitution across twigs within a branch but not across branches. 
Figure 1.

Tree Diagram for Choices after Completing JSS

This figure shows the tree structure of an individual's choices after completing Junior Secondary School (JSS), which are grouped by choice type: to attend Senior Secondary School (SSS) or to drop out of school.

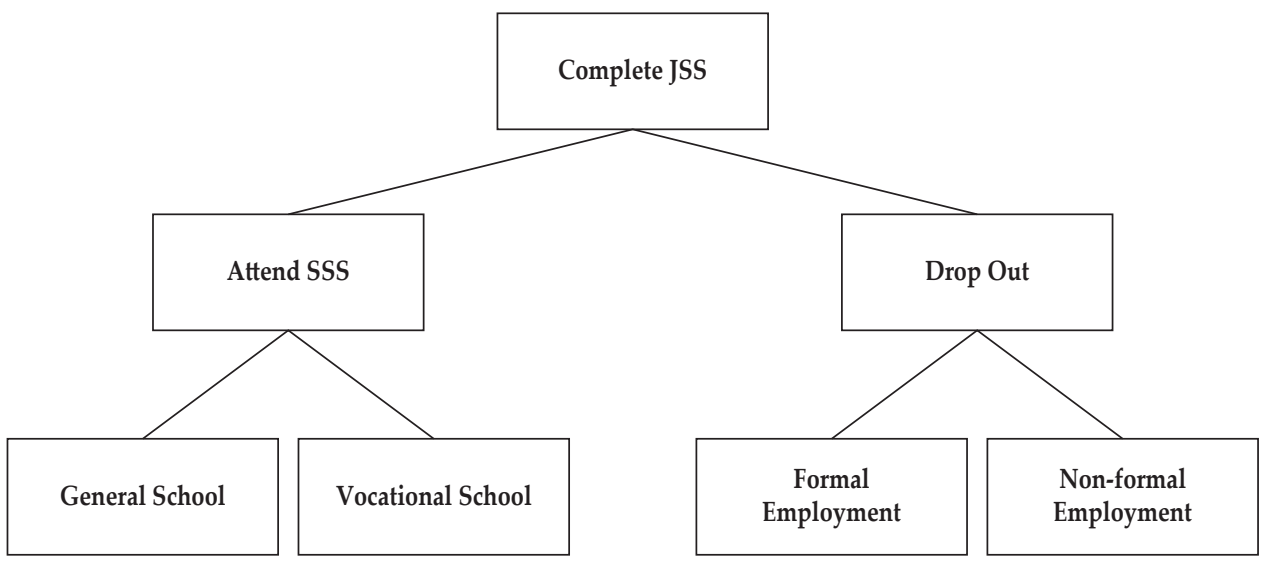

The nested logit model is estimated according to the following specification:

$$
\begin{aligned}
\text { schl_choice }_{i, t}= & \pi_{0}+\pi_{1} \ln M W_{j, t}+X_{i, t}^{\prime} \gamma_{1}+X_{h, t}^{\prime} \gamma_{2}+X_{j, t}^{\prime} \gamma_{3}+\varepsilon_{i, t} \\
& \text { schl_choice }_{i, t} \in 0,1
\end{aligned}
$$

The dependent variable schl_choice ${ }_{i, t}$ is a dummy variable that takes a value of zero if an individual $i$ drops out of school and one if an individual $i$ enrols at senior secondary school. The independent variable is $\ln M W_{j, t^{\prime}}$ where $M W_{j, t}$ is the real minimum wage of province $j$ at time $t . X_{i, t^{\prime}} X_{h, t^{\prime}}$ and $X_{i, t}$ are each vector of individual-, household-, and province-specific control variables. The parameters of the nested logit model are estimated by the simultaneous maximum likelihood technique, which, under fairly general conditions, generates consistent and efficient values of the parameters (Brownstone and Small, 1989). A positive value of the parameter $\pi_{1}$ indicates that an increase in the minimum wage is associated with an increase in the likelihood of senior secondary school enrolment. Meanwhile, a negative value of the parameter $\pi_{1}$ suggests that a hike in the minimum wage is linked to a drop in the probability of enrolling at senior secondary school, i.e., the individual is more like to drop out of school. The nested logit model in this study has two decision levels. In the first level, a type of choice is made-to enrol at senior secondary school or to drop out of school-and, in the second level, a specific alternative is chosen.

The nested logit model generalizes the multinomial logit model, allowing groups of alternatives to be similar in an unobserved way (Heiss, 2002). In the case of the two-level nested logit, as in this paper, it is assumed that there are $J$ choices of alternatives $\{0,1,2, \ldots, J\}$ nested into $S$ sets $\left\{B_{1}, B_{2}, \ldots, B_{s}\right\}$. The conditional probability of choice $j$ given the choice in the set $B_{s}$ becomes: 


$$
\operatorname{Pr}\left(Y_{i}=j \mid X_{i}, Y, \in B_{S}\right)=\frac{\exp \left(\rho_{s}^{-1} X_{i j}^{\prime} \beta\right)}{\Sigma_{l \in B_{S}} \exp \left(\rho_{s}^{-1} X_{i l}^{\prime} \beta\right)}
$$

for $j \in B_{s^{\prime}}$ and zero otherwise. In addition, the marginal probability of a choice in the set $B_{s}$ is as follows:

$$
\operatorname{Pr}\left(Y_{i} \in B_{S} \mid X_{i}\right)=\frac{\left(\Sigma_{l \in B_{s}} \exp \left(\rho_{s}^{-1} X_{i l}^{\prime} \beta\right)\right)^{\rho_{S}}}{\Sigma_{t=1}^{S}\left(\Sigma_{l \in B_{t}} \exp \left(\rho_{s}^{-1} X_{i l}^{\prime} \beta\right)\right)^{\rho_{S}}}
$$

If $\rho s=1$ for all $s$, then:

$$
\operatorname{Pr}\left(Y_{i}=j \mid X_{i}\right)=\frac{\exp \left(X_{i j}^{\prime} \beta+Z_{s}^{\prime} \alpha\right)}{\Sigma_{t=1}^{S}\left(\Sigma_{l \in B_{t}} \exp \left(X_{i j}^{\prime} \beta+Z_{s}^{\prime} \alpha\right)\right)}
$$

Thus, the implied joint distribution function of the $\varepsilon_{i, j}$ is:

$$
F\left(\epsilon_{i, 0}, \ldots, \epsilon_{i, J}\right)=\left(-\sum_{S=1}^{S}\left(\sum_{j \in B_{S}} \exp \left(-\rho^{-1} \varepsilon_{i, j}\right)\right)^{\rho_{s}}\right)
$$

$\rho_{s}$ indicates the degree of independence of alternatives within the nest, and $1-\rho_{s}$ is a measure of correlation within the nest. Meanwhile, between the sets, $\varepsilon_{i, j}$ are independent, in which $\rho_{s}=1$. When all correlations are zero, the nested logit model becomes the standard logit model.

The effect of minimum wage legislation on human capital investment relies on the firm's compliance level. In this respect, the government of Indonesia makes efforts to ensure that minimum wage laws are binding. According to Law No. 13 of 2003 concerning Manpower ${ }^{4}$, violating the minimum wage provision is a criminal offense and employers are threatened with a minimum of one year and a maximum of four years imprisonment and/or a minimum fine of Rp100 million (approximately US $\$ 6.8$ thousand) and a maximum of Rp 400 million (approximately US\$ 27 thousand). In addition to the law on Manpower, regulations regarding wages are also contained in Government Regulation (Peraturan Pemerintah/PP) No. 78 of 2015 concerning Wages/Remuneration ${ }^{5}$, Regulation of Minister of Manpower (Permenaker) No. 1 of 2017 concerning Wage Structure and Scale ${ }^{6}$, and Permenaker No. 15 of 2018 concerning Minimum Wages ${ }^{7}$. However, in practice, firms' primary motivation to comply with the minimum wage legislation is the possibility of labour strikes, which could disrupt the production process and the possibility of consumers boycotting the firms, affecting the firms' sales and revenue.

\footnotetext{
4 UU No.13/2003: https://peraturan.bpk.go.id/Home/Details/43013

5 PP No.78/2015: https://jdih.kemnaker.go.id/data_puu/PP_Nomor_78_Tahun_2015(1).pdf

6 Permenaker No.1/2017: https://jdih.kemnaker.go.id/data_wirata/wirata-4-1-2017.pdf

7 Permenaker No.15/2018: https://jdih.kemnaker.go.id/data_puu/Permen_15_2018.pdf
} 
Figure 2.

Kernel Density of Monthly Salary/Wage Distribution, 2000 and 2018

This figure displays the kernel density of Indonesia's salary distribution, as reported by Sakernas in 2000 and 2018. The evident spike in the salary distribution around the nominal minimum wage is observed each year, indicating that the minimum wage legislation, to a certain extent, has affected the salary distribution. This data is obtained from the National Labour Force Survey (Sakernas), 2000 and 2018.

2000

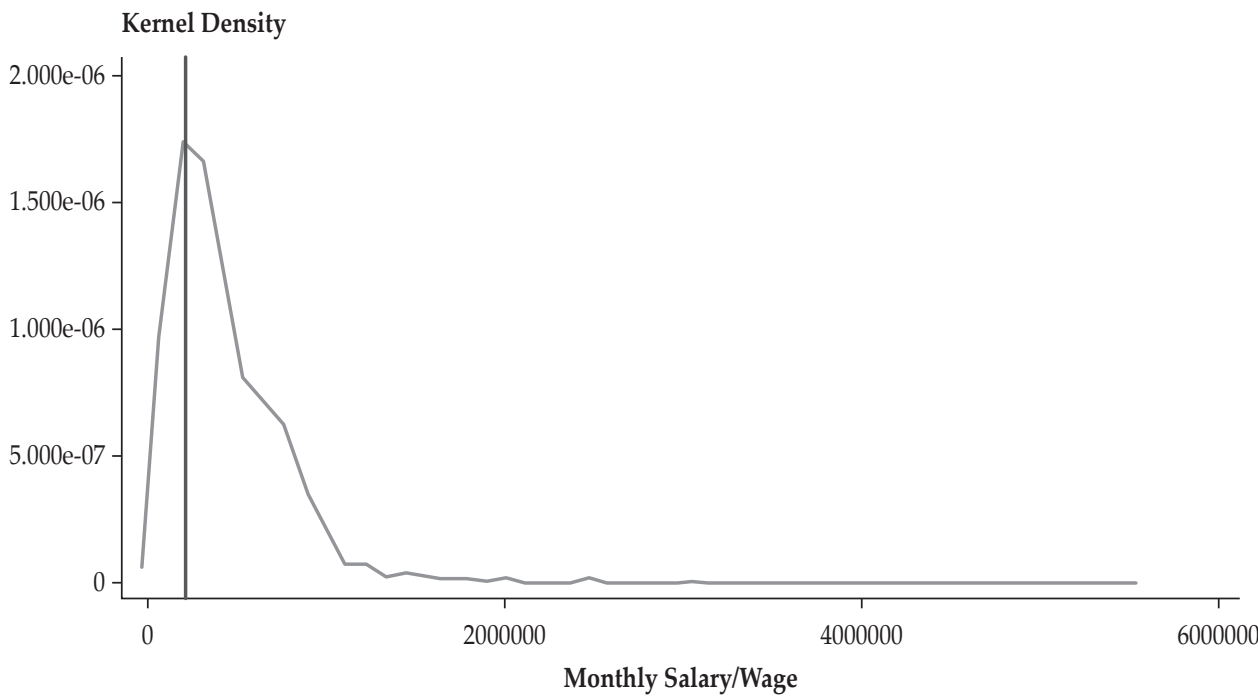

Kernel $=$ epanechnikov, bandwidth $=3.7 \mathrm{e}+04$

\section{Kernel Density}

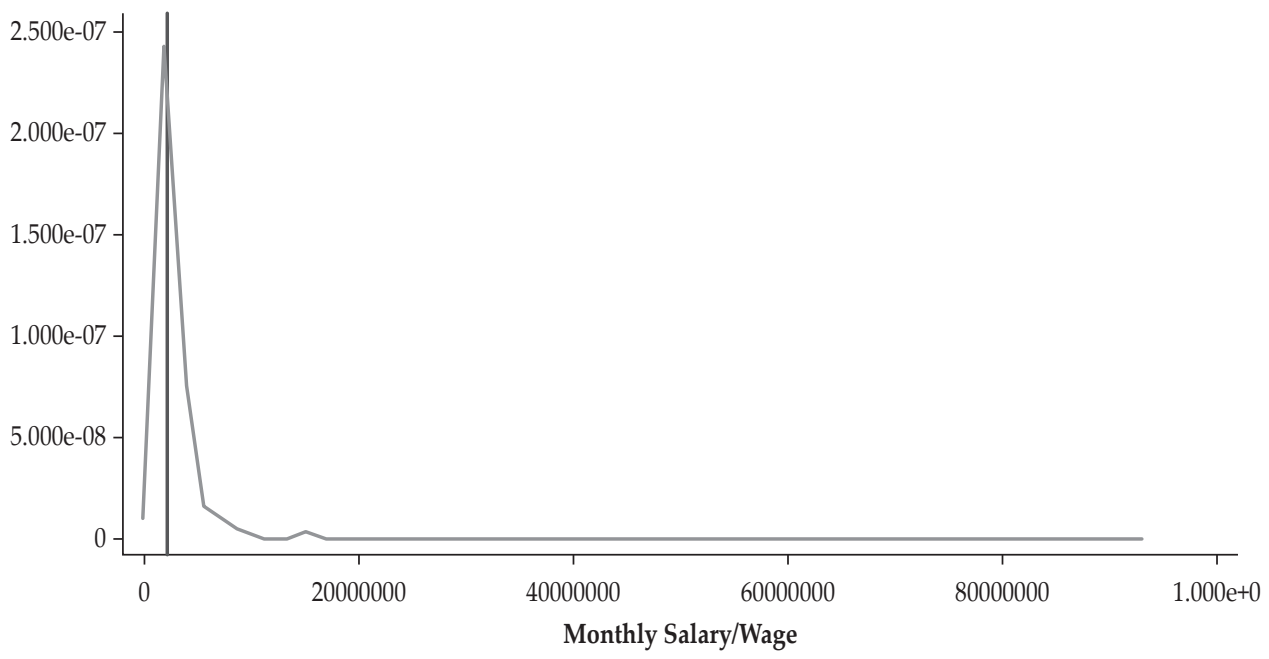

Kernel $=$ epanechnikov, bandwidth $=1.1 \mathrm{c}+05$ 
In addition, to ascertain that the regulation concerning minimum wage imposed by the government is binding, I performed further examination on the distribution of workers' wages and how it interacts with the minimum wage level. Figure 2 displays the kernel density of the salary distribution in Indonesia, as reported by Sakernas in 2000 and 2018, which were chosen since the survey data used in the analysis are from 2000 to 2018. The national average of the nominal minimum wage is depicted by the red vertical line. In this case, an evident spike in the salary distribution around the nominal minimum wage is observed each year, indicating that the minimum wage legislation, to a certain extent, has affected the salary distribution. The proportion of workers who received wages above the minimum wage amounts to 91 percent in 2000. Yet, it decreased to 63 percent in 2018, along with a significant increase in the minimum wage level. Despite firms' imperfect compliance on minimum wage-since a proportion of workers is still receiving wage below the minimum wage-the evidence shown in Figure 2 could sufficiently become the foundation that allows the analysis using minimum wage.

\section{MAIN FINDINGS}

\section{A. Minimum Wage Effect on Choice of Senior Secondary School Type}

Table 1 presents the effect of minimum wage legislation on the choice of human capital investment, estimated using Equation (9). Column (1) contains the estimate for the full sample, Columns (2) and (3) show the estimates when the sample is disaggregated by gender, whereas Columns (4) and (5) display the estimates when the sample is subdivided based on household income.

Table 1.

The Effect of Minimum Wage on the Choice of Human Capital Investment

This table reports the estimates using the nested logit model for the full sample and when the sample is disaggregated by gender and household income. Dependent Variable is the Choice of Human Capital Investment ( $0=$ Drop Out of School; $1=$ Enrol at Senior Secondary School). Standard errors robust to heteroscedasticity are in the parentheses. ${ }^{*}, * *$, and ${ }^{* * *}$ denote statistical significance at the $10 \%, 5 \%$, and $1 \%$ levels, respectively. All estimations include all the control variables described in Section III as well as year and province fixed effects.

\begin{tabular}{lccccc}
\hline & $\mathbf{( 1 )}$ & $\mathbf{( 2 )}$ & $\mathbf{( 3 )}$ & $\mathbf{( 4 )}$ & $\mathbf{( 5 )}$ \\
\cline { 2 - 6 } & Baseline & Male & Female & $\begin{array}{c}\text { Low } \\
\text { Income }\end{array}$ & $\begin{array}{c}\text { High } \\
\text { Income }\end{array}$ \\
\hline Log (minimum wage) & $-.187^{* *}$ & -.083 & $-.377^{* *}$ & $.207^{* * *}$ & -.018 \\
& $(.089)$ & $(.128)$ & $(.128)$ & $(.059)$ & $(.134)$ \\
Odds ratio & .829 & .920 & .685 & 1.229 & .981 \\
Wald $\chi^{2}$ & 766.07 & 612.00 & 436.01 & 2992.19 & 395.93 \\
Log likelihood & -2039.51 & -1162.79 & -959.55 & -12152.83 & -1100.89 \\
Observations & 11,088 & 5,616 & 5,472 & 5,292 & 5,796 \\
\hline
\end{tabular}

Based on the estimation using the nested logit model, the estimated effect of minimum wage is negative and statistically significant at a 5 percent significance level for the full sample regression. The coefficient of the nested logit estimation is in terms of log odds. When the outcome is converted to odds ratio by taking the exponent, it could be inferred that the odds are 0.83 to 1 (17 percent decrease in the 
odds) that parents will invest in their children's education with $e$ (or approximately 2.718) times increase in the minimum wage. ${ }^{8}$ This result suggests that an increase in the minimum wage is associated with lower odds to enrol at senior secondary school. The finding of this negative effect is also in accordance with the previous studies conducted by Neumark and Wascher (1994), Landon (1997), Pacheco (2007), and Rice (2010).

Furthermore, to capture gender differences in the effect of minimum wage, the sample is disaggregated into male and female. There is no significant effect of minimum wage for the male sample regression, indicating that deciding whether to attend senior secondary school is not influenced by the minimum wage legislation. Meanwhile, when the same regression is carried out using the female sample, the results indicate a negative effect of minimum wage on educational investment, which is significant at the 5 percent level. The odds are 0.68 to 1 (32 percent decrease in the odds) that parents will invest in their female children's education with $e$ times increase in the minimum wage.

There are two possible explanations for this negative result in the female sample. First, the substitution effect could be dominant, as shown in Equation (7). Thus, a female child will have a higher probability of dropping out of senior secondary school as the minimum wage legislation reduces the skill premium and the net benefit of sending a female child to school. Second, the income effect could be larger than the substitution effect but then it is offset by a rise in the probability of obtaining a low-skilled employment; hence, an increase in the minimum wage is accompanied by higher odds of a female child dropping out of senior secondary school.

Statistically, at the 5 percent significance level, the disaggregation reveals that the odds ratio among male children is 31 percent higher than that of female children to enrol at senior secondary school due to the minimum wage increase. ${ }^{9}$ This result indicates that female children are more likely to drop out of school and to start working, either in the formal or informal sector, as minimum wage increases. This could be explained by the entrenched cultural norms concerning women's role in society, particularly in many developing countries. Besides, rooted norms on gender division of labour in which women are supposed to take care of the domestic work will most likely bias education investment towards males (Dreze and Sen, 1995; Davies and Zhang, 1995; Chen et al., 2009). In Indonesia, although there is no evidence of son preference in birth spacing, Kevane and Levine (2003) suggest that gender differences in educational attainment-particularly in senior secondary and tertiary education-and inheritance were quite prevalent in the recent past.

Furthermore, the sample is subdivided by household income proxied using household expenditure data, which was timely and spatially standardised to generate comparable figures across time and province in Indonesia. This disaggregation is crucial to analyse possible differences in the effect of minimum

8 The odds ratio is associated with a $b$-fold increase in the predictor, where $b$ is the base of the logarithm used when log-transforming the predictor.

9 Odds ratio among male children is 1 because there is no significant result on the effect of minimum wage legislation on senior secondary school enrolment. Hence, in this case, the condition whether to attend senior secondary school is equally likely to occur. 
wage between low-income and high-income households in the sample. The intuition is that the effect of the positive income shock would be more likely to affect households with income below the minimum wage rate. Conversely, households with income that lies well above the minimum wage rate should experience none or comparatively smaller effect on their income. For this purpose, a low-income household is defined as a household that receives real monthly income less or equal to the equivalent value of 800,000 rupiahs in 2010, while any household with income above this threshold is defined as a high-income household. This subdivision threshold is also consistent with the average of the real minimum wage in 2010, which is 845,707 rupiah. We separately run the regression based on household income status, and present the results in Columns (4) and (5). The estimate of minimum wage effect is negative for individuals in the high-income households and yet positive for individuals in low-income households.

According to the estimates using the nested logit model, the estimated effect of minimum wage is positive and statistically significant at the 1 percent significance level for the low-income sample regression. If it is interpreted using the odds ratio, I could conclude that the odds are 1.22 to 1 (22 percent increase in the odds) that parents will invest in their children's education with $e$ times increase in the minimum wage. Meanwhile, when the same regression is carried out using the high-income sample, I find no significant effect of minimum wage on educational investment. The significant positive effect of minimum wage legislation among the low-income households indicates that an increase in the minimum wage is associated with a higher probability to enrol at senior secondary school. This result is in accordance with the theoretical prediction that the budget constraint in condition (8) is more likely to be binding for the low-income households; hence a positive income shock will make it less binding resulting in a higher probability of investing in senior secondary education. Moreover, the result is also consistent with the intuition that individuals in households at the lower end of the income distribution are more sensitive to an increase in the minimum wage.

Nevertheless, among the low-income households, it cannot be concluded that the income effect is the dominant factor (relative to the substitution effect) as this positive result may be generated by a fall in the probability of obtaining lowskilled employment that offset the substitution effect. In other words, if the labour market in Indonesia is assumed to be competitive, as suggested by Suryahadi et al. (2003) that firms substituted low-skilled workers for high-skilled workers, the dominant substitution effect (i.e., to drop out of school) may be superseded by the lower probability of employment due to a higher minimum wage. As a result, the probability of enrolling in senior secondary school is higher. In this regard, Cameron and Alatas (2003), using census data from all medium and large Indonesian firms, find evidence of an adverse employment impact for small domestic firms but no employment impact for large firms - foreign or domestic. This result indicates that smaller firms, in particular, operate in a competitive labour market in Indonesia.

Although minimum wages may not directly affect low-income households since a significant proportion of them is engaged in the informal sector ${ }^{10}$, empirical

${ }_{10}$ According Sakernas 2019, more than 55 percent of workers in Indonesia are involved in informal sector employment. This rate is higher among poor workers, approximately 65 percent of workers with income in the bottom 20 percent work in the informal sector. 
studies reveal that they play a significant role. As an instance, a study by Khamis (2013) finds that the rise in the minimum wage has had only a minor effect on the formal sector in Argentina but has improved wages in the informal sector. This result indicates that the common practice of non-compliance with labour laws and standards in the informal economy does not necessarily imply that minimum wages do not affect. The rationale for the influence of minimum wages on wages received by informal workers has been the "lighthouse effect" -i.e., a signal given by the minimum wage legislation to workers and employers in the informal economy regarding socially acceptable minimum levels of pay (Souza and Baltar, 1979; Bell, 1999). In line with this, a field investigation in Indonesia conducted by Widarti (2006) observes that the wage system in the informal sector uses wage references in the regions' similar businesses; therefore, wages for most workers in the informal sector are clustered around the minimum wage standards at the provincial level.

\section{B. Separating the Substitution and Income Effects}

Determining the magnitude of substitution and income effect is also of interest in analysing the effect of minimum wage on educational investment. Several additional assumptions underlying this identification are needed. First, the magnitude of the substitution effect is symmetric across low-income and highincome households. Second, as the effect of the positive income shock is more likely to affect households with income below the minimum wage rate, the income effect is assumed to affect only low-income households; and, third, the labour market is competitive so that an increase in the minimum wage is followed by an adverse effect in employment. To determine the size of substitution and income effects, I estimate the following regression:

$$
\begin{aligned}
\text { choice }_{i, t}=\pi_{0}+\pi_{1} \operatorname{lnMW}_{j, t}+ & \pi_{2} \text { Low Income }_{i, t}+\pi_{3}\left(\text { Low Income }_{i, t} * \ln _{\text {In }} W_{j, t}\right)+ \\
& \boldsymbol{X}_{\boldsymbol{i}, \boldsymbol{t}}^{\prime} \boldsymbol{\gamma}_{\mathbf{1}}+\boldsymbol{X}_{\boldsymbol{h}, \boldsymbol{t}} \boldsymbol{\gamma}_{\mathbf{2}}+\boldsymbol{X}^{\prime}{ }_{\boldsymbol{j}, \boldsymbol{t}} \boldsymbol{\gamma}_{\mathbf{3}}+\varepsilon_{i, t} \\
& \text { schl_choice }_{i, t} \in 0,1
\end{aligned}
$$

Low Income is a dummy variable taking the value of 1 if the household is classified as low income (i.e. receiving real monthly income less or equal to the equivalent value of 800,000 rupiahs in 2010) and 0 if otherwise. According to Equation (14), $\pi_{1}$ will capture the common effect of minimum wage across all households. Meanwhile, $\pi_{3^{\prime}}$ the coefficient of the interaction term, will capture the additional effect of minimum wage specific to the low-income household. Given the aforementioned assumptions, $\pi_{1}$ will capture the substitution effect for both households, and thus the sign is expected to be negative, whereas $\pi_{3}$ will capture the income effect for low-income households, and the sign should be positive. 
Table 2.

\section{Alternative Specification with Interaction Term}

This table reports the results using the nested logit model with an interaction term. All estimations include all the control variables described in Section III as well as year and province fixed effects. Dependent Variable is the Choice of Human Capital Investment (0=Drop Out of School; 1= Enrol at Senior Secondary School)

\begin{tabular}{lcccc}
\hline & Coefficient & $\begin{array}{c}\text { Standard } \\
\text { Error }\end{array}$ & $\boldsymbol{z}$ & $\boldsymbol{P}>|\boldsymbol{z}|$ \\
\hline Log (minimum wage) & -0.126 & 0.026 & -4.91 & 0.000 \\
Low Income & 2.538 & 5.968 & 0.43 & 0.671 \\
Low Income* $\log$ (minimum wage) & -0.202 & 0.416 & -0.49 & 0.627 \\
\hline
\end{tabular}

Based on the regression specified in Equation (14), Table 2 shows that the coefficient of log real minimum wage is negative, whereas the coefficient of the interaction term is insignificant. From these results, it can be inferred that the substitution effect is dominant for both households, whereas the income effect is non-existent for low-income households. Hence, the positive and significant effect of an increase in minimum wage among low-income households, presented in Column (4) of Table 1, is more likely to be associated with a fall in the probability of obtaining a low-skilled employment that offset the substitution effect, rather than with the income effect on its own.

\section{Standard Logit or Nested Logit Model}

In order to check whether a nested logit model provides an accurate representation of the substitution pattern, I performed hypothesis tests on the correlations within a nested logit model (Train, 2009). When all correlations are zero, the generalised extreme value distribution becomes the product of independent extreme value distributions, and the nested logit model becomes a standard logit model. In contrast, if there are correlations over alternatives, the nested logit model is the appropriate model to be used for the analysis.

The coefficient on the inclusive value $\left(\rho_{s}\right)$, sometimes called the log-sum coefficient or the dissimilarity parameter, reflects the degree of independence among the unobserved portions of utility for the alternatives in each nest. A high value of $\rho_{s}$ means greater independence and less correlation, i.e., the alternatives in the nest are less similar for unobserved reasons. For a nested logit model to be consistent with utility-maximising behaviour, it must be the case that $0<\rho_{s}<1$ for all $s$. A negative value of $\rho_{s}$ is inconsistent with utility maximisation since it implies that improving the attributes of an alternative actually decreases the probability that it will be chosen. In general, the estimated log-sum coefficient that is outside the $(0,1]$ bound suggests a misspecification problem with the model, in which either the systematic component, the grouping, or both could be incorrectly specified. Table 3 exhibits that the log-sum coefficients in all nested logit model specifications satisfy $0<\rho_{s}<1$ for all $s$. Thus, it can be inferred that there is no misspecification problem with the model. 
Table 3.

\section{Dissimilarity Parameters, LR Test, and Hausman Test for IIA}

This table reports the dissimilarity parameters, LR test, and Hausman Test for IIA for the full sample and when the sample is disaggregated by gender and household income. Dependent Variable is the Choice of Human Capital Investment (0=Drop Out of School; $1=$ Enrol at Senior Secondary School). Standard errors robust to heteroscedasticity are in the parentheses. ${ }^{*} * *$, and ${ }^{* *}$ denote statistical significance at the $10 \%, 5 \%$, and $1 \%$ levels, respectively. All estimations include all the control variables described in Section III as well as year and province fixed effects.

\begin{tabular}{|c|c|c|c|c|c|}
\hline & $\begin{array}{c}\text { (1) } \\
\text { Baseline }\end{array}$ & $\begin{array}{l}(2) \\
\text { Male }\end{array}$ & $\begin{array}{c}\text { (3) } \\
\text { Female }\end{array}$ & $\begin{array}{c}(4) \\
\text { Low Income }\end{array}$ & $\begin{array}{c}(5) \\
\text { High } \\
\text { Income }\end{array}$ \\
\hline$\rho_{\text {Senior Secondary School }}$ & .624 & .668 & .716 & .770 & .653 \\
\hline$\rho_{\text {Drop Out }}$ & .332 & .436 & .249 & .407 & .358 \\
\hline $\begin{array}{l}\text { LR test for IIA } \\
\left(H_{0}: \rho_{s}=1 \forall s\right)\end{array}$ & $26.55^{* * *}$ & $36.72^{* * *}$ & $61.59^{* * *}$ & $98.44^{* * *}$ & $26.93^{* * *}$ \\
\hline $\begin{array}{l}\text { Hausman test for IIA } \\
\left(H_{0}: \rho_{s}=1 \forall s\right)\end{array}$ & $42.38^{* * *}$ & $44.88^{* * *}$ & $94.37^{* * *}$ & $468.14^{* * *}$ & $33.00^{* * *}$ \\
\hline
\end{tabular}

In addition, to check whether the model has complete independence and the nested logit reduces to a standard logit model, a Likelihood-Ratio (LR) test is conducted with the null being that $\rho_{s}=1$ for all $s$. In the case of this paper, the LR test results in Table 3 show that the null that all of the dissimilarity parameters are 1 can be rejected at the 1 percent significance level for all of the nested logit model specifications. This indicates that the nested logit model is, in fact, more appropriate to estimate the effect of minimum wage on educational investment as compared to the standard logit model, especially when the type of senior secondary school and employment pose as alternatives that one has to choose. The joint test that $\rho_{s}=1$ for all $s$ can also be seen as a test of the IIA assumption. If $\rho_{s}=1$ for all $s$, which means that the IIA holds, then it is appropriate to use the standard logit model. Nevertheless, the LR test result should be used with caution as it will depend on exactly how the decision tree is specified. In other words, different specifications of the decision tree can lead to conflicting results. Therefore, Hausman's (1978) specification test can be used to test for IIA, because this test is not be sensitive to the tree structure specified in the nested logit model. Table 3 also reports Hausman's specification test results, which indicate that IIA does not hold, and thus it is appropriate to use the nested logit model.

\section{Disaggregation into High- and Low-income Household}

The regressions for low- and high-income households presented in Table 1 use the sample disaggregated by the equivalent value of $\mathrm{Rp} \mathrm{800,000} \mathrm{in} 2010$ cutoff, an arbitrary threshold set to examine the heterogeneity of minimum wage effect based on the household income. To check for robustness, this section repeats the regression done in Columns (4) and (5) of Table 1 using different sample subdivisions. Table 4 presents the estimates of minimum wage effect on educational investment when the sample is disaggregated into three groups based on household income distribution. 
Table 4.

\section{Estimation of Minimum Wages Effect on Educational Investment Based on the Household Income Distribution}

This table reports the results using the nested logit model for the full sample and when the sample is disaggregated by gender and household income. Dependent Variable is the Choice of Human Capital Investment (0=Drop Out of School; $1=$ Enrol at Senior Secondary School). Standard errors robust to heteroscedasticity are in the parentheses. ${ }^{*}, * *$, and ${ }^{* * *}$ denote statistical significance at the $10 \%, 5 \%$, and $1 \%$ levels, respectively. All estimations include all the control variables described in Section III as well as year and province fixed effects.

\begin{tabular}{|c|c|c|c|c|}
\hline & (1) & (2) & (3) & (4) \\
\hline & $\begin{array}{l}\mathrm{HH} \text { income } \leq \\
5^{\text {th }} \text { percentile }\end{array}$ & $\begin{array}{l}\text { HH income } \leq \\
25^{\text {th }} \text { percentile }\end{array}$ & $\begin{array}{c}25^{\text {th }} \text { percentile }> \\
\text { HH income } \leq \\
50^{\text {th }} \text { percentile }\end{array}$ & $\begin{array}{l}\text { HH income }> \\
50^{\text {th }} \text { percentile }\end{array}$ \\
\hline Log (Minimum Wages) & $\begin{array}{l}0.249^{* * *} \\
(0.0700)\end{array}$ & $\begin{array}{l}-0.115 \\
(0.0830)\end{array}$ & $\begin{array}{l}-0.0415 \\
(0.104)\end{array}$ & $\begin{array}{l}-0.0533 \\
(0.203)\end{array}$ \\
\hline Odds ratio & 1.282 & .891 & .959 & .948 \\
\hline Wald $\chi^{2}$ & 2174.49 & 1141.14 & 1265.23 & 454.46 \\
\hline Log likelihood & -8695.10 & -4332.77 & -5005.53 & -975.97 \\
\hline Observations & 2,439 & 2,772 & 2,661 & 3,216 \\
\hline
\end{tabular}

The threshold for the $5^{\text {th }}$ percentile of household income distribution is the equivalent value of $\operatorname{Rp} 817,165$ in 2010 , whereas the $25^{\text {th }}$ and $50^{\text {th }}$ percentiles of the distribution are the equivalent values of $\operatorname{Rp} 1,287,747$ and $R p 1,796,012$ in 2010, respectively. Column (1) shows that the minimum wage legislation has a significant positive effect on educational investment. In other words, an increase in minimum wage induces enrolment in senior secondary school among individuals in low-income households, particularly those with income below 5 percent of the distribution. Using the odds ratio, I could conclude that the odds are 1.252 to 1 that parents will invest in their children's education with $e$ times increase in the minimum wage. Conversely, Columns (2), (3), and (4) display that there is no significant effect of minimum wage on educational investment. This is consistent with the regression estimates for low- and high-income households in Table 1, indicating that the significant positive effect of minimum wage among the lowincome households is mostly driven by individuals whose household incomes are at the $5^{\text {th }}$ percentile of the distribution, which is equal to the average value of real minimum wage in 2010.

\section{E. Construction of Provincial Real Minimum Wage Variable}

One could use the Consumer Price Index (CPI) or the Gross Domestic Product (GDP) deflator to adjust nominal values to real values. Although it may seem that both measure the same thing at first glance, there are a few key differences. The first is that the GDP deflator includes only domestic goods and not anything that is imported, whereas the CPI includes anything bought by consumers, including foreign goods. The second difference is that the GDP deflator is a measure of the prices of all goods and services, whereas the CPI is a measure of only goods bought by consumers. Therefore, this section presents a robustness check, which entails constructing the provincial real minimum wage variable using $\mathrm{CPI}$ as a deflator, rather than the GDP deflator. 
Table 5.

\section{The Effect of Minimum Wage on the Choice of Human Capital Investment}

This table reports the results using the nested logit model for the full sample and when the sample is disaggregated by gender and household income. Dependent Variable is the Choice of Human Capital Investment (0=Drop Out of School; $1=$ Enrol at Senior Secondary School). Standard errors robust to heteroscedasticity are in the parentheses. ${ }^{* * *}$, and ${ }^{* * *}$ denote statistical significance at the $10 \%, 5 \%$, and $1 \%$ levels, respectively. All estimations include all the control variables described in Section III as well as year and province fixed effects.

\begin{tabular}{lccccc}
\hline & $\mathbf{( 1 )}$ & $\mathbf{( 2 )}$ & $\mathbf{( 3 )}$ & $\mathbf{( 4 )}$ & $\mathbf{( 5 )}$ \\
\cline { 2 - 6 } & Baseline & Male & Female & $\begin{array}{c}\text { Low } \\
\text { Income }\end{array}$ & $\begin{array}{c}\text { High } \\
\text { Income }\end{array}$ \\
\hline Log (minimum wage) & $-.182^{*}$ & -.088 & $-.300^{* *}$ & $.287^{* * *}$ & -0.107 \\
& $(.106)$ & $(.137)$ & $(.152)$ & $(.076)$ & $(.228)$ \\
Odds ratio & .833 & .914 & .740 & 1.332 & 0.898 \\
Wald $\chi^{2}$ & 702.50 & 319.38 & 409.41 & 2171.33 & 251.55 \\
Log likelihood & -1794.43 & -1011.75 & -860.49 & -8737.72 & -616.28 \\
Observations & 11,088 & 5,616 & 5,472 & 5,292 & 5,796 \\
\hline
\end{tabular}

The national CPI data in Indonesia is constructed based on CPI data available at the city or district level, which represents all provinces in Indonesia. The number of cities used to survey the cost of living has increased across the years. In 2000, the CPI was based on surveys in 44 cities; then, it became 45 cities in 2004, 66 cities in 2008, and 82 cities in 2014. Although there is no CPI data at the provincial level, I construct the provincial level CPI using data at the city and district level by weighting cities that represent the province based on their GDP relative to the provincial GDP. Table 5 presents the estimates of the minimum wage effect on educational investment, where the provincial real minimum wage variable is constructed by dividing the provincial nominal minimum wage with the value of provincial CPI each year to index the variable in terms of 2010 rupiah.

Based on the estimates using the nested logit model, the estimated effect of the minimum wage is negative and statistically significant at the 10 percent significance level for the full sample. It could be inferred that the odds are 0.83 to 1 (17 percent decrease in the odds) that parents will invest in their children's education with $e$ times increase in the minimum wage. Meanwhile, when the sample is disaggregated according to gender, the male sample regression estimates do not show any significant effect of minimum wage on educational investment. However, among the female sample, there is evidence that a higher minimum wage is linked to the likelihood of dropping out of school, significant at the 5 percent significance level. The odds are 0.74 to 1 (26 percent decrease in the odds) that parents will invest in their female children's education with e (or approximately 2.718 ) times increase in the minimum wage.

Furthermore, according to the household income disaggregation, the estimated effect of minimum wage is positive and statistically significant at the 1 percent significance level among low-income households. Using the odds ratio, I could conclude that the odds are 1.33 to 1 (33 percent increase in the odds) that parents will invest in their children's education with $e$ times increase in the minimum wage. Meanwhile, when the same regression is carried out using the high-income 
sample, there is no significant effect of minimum wage on educational investment. The significant positive effect of minimum wage legislation among the low-income households indicates that an increase in the minimum wage is associated with a higher probability to enrol at senior secondary school.

As explained in Section III, the provincial real minimum wage variable in this paper is created by dividing the provincial nominal minimum wage with the provincial GDP price deflator in each year to index the variable in terms of 2010 rupiah. However, the robustness-check regression results show no significant differences between using the provincial GDP deflator and the CPI to convert minimum wage to real terms. Both show significant positive effects of the minimum wage increase on the odds of senior secondary school enrolment among the low-income households, and significant negative effects for the full sample. Moreover, the size of the odds ratio between the two types of regressions suggests no significant dissimilarity.

\section{F. Discussion and Limitations}

In a pooled cross-sectional data setting, one is unable to fully control for timeinvariant unobservable characteristics like in a panel data setting. As a result, both the time-variant and invariant unobservable characteristics, which affect the school choice, will lead to endogeneity bias if they are correlated with the independent variables and are not directly controlled. Therefore, in this paper, whenever possible, both the time-variant and invariant factors that have the potential to cause endogeneity bias are controlled. Nevertheless, data on some important control variables are unavailable, including data on the direct cost of senior secondary education and a proxy for education quality, such as teachers' salaries or the student-teacher ratio. There is a concern that the minimum wage variable might be correlated with these unobservable factors, which would then determine educational investment and lead to possible endogeneity bias. For instance, if the direct cost of senior secondary education is positively correlated with minimum wage, as this cost is part of the decent living standard consumption bundle determining the minimum wage rate, the coefficient of the minimum wage variable will be biased upwards. Given the availability of data on these control variables, this could improve the precision of the estimates in this paper.

Here, the parameters of the nested logit model are simultaneously estimated using the standard maximum likelihood technique. Although maximisation using maximum likelihood is sometimes challenging because the log-likelihood function is not globally concave and even in concave areas is not close to a quadratic, the nested logit model results are consistent (Brownstone and Small, 1989). With simultaneous estimation, the nested logit model's parameters are efficient since all information is utilised in the estimation of each parameter, and parameters that are common across components are necessarily constrained to be equal (Train, 2009). Nevertheless, in some cases, if problems arise in the simultaneous estimation, nested logit models can be estimated in a sequential manner, which is performed "bottom-up". However, conforming to Train (2009), the sequential estimation of nested logit models, while consistent, is not as efficient as simultaneous estimation by maximum likelihood. In the case of the nested logit model in this paper, there 
is no problem in the simultaneous estimation, and the log-likelihood has a unique global maximum. Therefore, there is little reason to sequentially estimate the nested logit model.

\section{CONCLUSION AND POLICY IMPLICATIONS}

This paper shows that Indonesia's minimum wage legislation has a significantly negative effect on educational investment. Individuals are more likely to drop out of senior secondary school following an increase in the minimum wage. The estimates indicate that female children are more likely to drop out of school and start working, either in the formal or informal sector, as the minimum wage increases. Furthermore, after disaggregating the sample by household income, I document that an increase in the minimum wage has no effect on education investment for individuals in high-income households, whereas it has a positive effect for individuals in low-income households. Nevertheless, using these incomedivision results alone, I cannot conclude that the income effect is the dominant factor among low-income households since the positive effect of minimum wage may be generated by a fall in the probability of obtaining low-skilled employment that offset the substitution effect. Therefore, to separate the substitution and income effects, I estimate a regression incorporating an interaction term. The results suggest that the substitution effect is the dominant factor in explaining the effect of minimum wage legislation on human capital investment, both for lowand high-income households. This dominant and negative substitution effect is also discovered in most studies analysing the impact of minimum wage on human capital investment, such as Neumark and Wascher (1994), Landon (1997), Pacheco (2007), and Rice (2010).

This study shows that low-income households, particularly those with income below 5 percent of the distribution, are more sensitive to changes in the minimum wage. A positive income shock through an increase in the minimum wage for the low-income household would make their budget constraint less binding, resulting in a higher probability of investing in senior secondary education. However, a positive income shock is not only in the form of an increase in the minimum wage but may also be in the form of social assistance distributed to ease households' expenses. Therefore, to preserve the positive response among low-income household, active government policy is critical to support poor households to invest in their human capital, instead of saving for precautionary reasons. In addition, the government should also ensure adequate coverage and benefit levels of social assistance as they are vital in protecting human capital and building resilience. Moreover, a well-functioning, adaptive, and responsive social protection system is a prerequisite to protect poor and vulnerable households against risks and shocks along the lifecycle. Such social protection system would minimise negative coping behaviours (e.g., giving up productive investment in order to maintain basic minimum consumption) and contribute to beneficiaries' human and financial capital in the long run.

Besides, the empirical results in this study suggest that an increase in the minimum wage thwarts recent government efforts to promote student enrolment in senior secondary school. Consequently, the impact on human capital investment 
decisions of individuals should be taken into account when considering the costs and benefits of introducing or raising the minimum wage. Policy interventions may be crucial to encourage students to complete senior secondary school, mainly to counteract the negative impact of the minimum wage legislation on educational investment and to avert the negative consequences in terms of long-run economic development of labour force with a low level of human capital. Moreover, the results indicate that the success of a government programme will depend at least in part on other programmes. Therefore, inter-sectoral policy coordination should be improved to enable synergy or at least prevent overlapping and conflicts of sectoral policies, which is increasingly vital due to the growing complexity of many policy issues. The government needs to identify and mitigate divergences between sectoral priorities and policies and promote mutually supporting actions across sectors and institutions.

\section{REFERENCES}

Acemoglu, D., \& Autor, D. (2000). Lectures in Labour Economics. https://economics. mit.edu/files/4689

Acemoglu, D., \& Pischke, J. S. (2001). Changes in the Wage Structure, Family Income, and Children's Education. European Economic Review, 45, 890-904.

Becker, G. S. (1964). Human Capital: A Theoretical and Empirical Analysis with Special Reference to Education (3rd Edition). The University of Chicago Press.

Becker, G. S., \& Tomes, N. (1986). Human capital and the Rise and Fall of Families. Journal of Labour Economics, 4, 1-47.

Bell, L. A. (1999). The Impact of Minimum Wages in Mexico and Colombia. The World Bank.

Brown, C., Gilroy, C., \& Kohen, A. (1982). The Effect of the Minimum Wage on Employment and Unemployment. Journal of Economic literature, 20, 487-528.

Brownstone, D., \& Small, K.A. (1989). Efficient Estimation of Nested Logit Models. Journal of Business Economic Statistics, 27, 67-74.

Cahuc, P., \& Michel, P. (1996). Minimum Wage Unemployment and Growth. European Economic Review, 40, 1463-1482.

Cameron, L. A., \& Alatas, V. (2003). The Impact of Minimum Wages on Employment in a Low-income Country: An Evaluation Using the Difference-in-differences Approach. The World Bank.

Card, D., \& Krueger, A. B. (1993). Minimum Wage and Employment: A Case Study of the Fast-food Industry in New Jersey and Pennsylvania (No. w4509). National Bureau of Economic Research.

Chaplin, D. D., Turner, M. D., \& Pape, A. D. (2003). Minimum Wage and School Enrolment of Teenagers: A Look at the 1990s. Economics of Education Review, 22,11-21.

Chen, D. (2009). Vocational Schooling, Labour Market Outcomes, and College Entry (No. 4814). The World Bank.

Chun, N., \& Khor, N. (2010). Minimum Wage and Changing Wage Inequality in Indonesia (No. 196). Asian Development Bank.

Davies, J. B., \& Zhang, J., (1995). Gender Bias, Investments in Children, and Bequests. International Economic Review, 795-818. 
Dreze, J., Sen, A., \& Hussain, A. (1995). The Political Economy of Hunger: Selected Essays. Oxford University Press.

Ehrenberg, R. G., \& Marcus, A. J. (1982). Minimum Wage and Teenagers' Enrolment-Employment Outcomes: A Multinomial Logit Model. Journal of Human Resources, 39-58.

Hausman, J. A. (1978). Specification Tests in Econometrics. Econometrica, 46, 12511271.

Heiss, F. (2002). Structural Choice Analysis with Nested Logit Models. The Stata Journal, 2, 227-252.

Hohberg, M., \& Lay, J. (2015). The Impact of Minimum Wage on Informal and Formal Labour Market Outcomes: Evidence from Indonesia. IZA Journal of Labour Development, 4, 14.

Johnston, D., \& Morduch, J. (2008). The Unbanked: Evidence from Indonesia. The World Bank Economic Review, 22, 517-537.

Khamis, M. (2013). Does the Minimum Wage Have a Higher Impact on the Informal than on the Formal Labour Market? Evidence from Quasi-experiments. Applied Economics, 45, 477-495.

Landon, S. (1997). High School Enrolment, Minimum Wage and Education Spending. Canadian Public Policy/Analyse de Politiques, 141-163.

Mattila, J. P. (1978). Youth Labour Markets, Enrolments, and Minimum Wage. In Proceedings of the 31st Annual Meeting, Industrial Relations Research Association Series (pp. 134-40).

Neumark, D., \& Wascher, W. (1994). Minimum Wage Effects and Low-wage Labour Markets: A Disequilibrium Approach (No. w4617). National Bureau of Economic Research.

Neumark, D., \& Wascher, W. L. (2007). Minimum Wage and Employment. Foundations and Trends in Microeconomics, 3, 1-182.

Pacheco, G. A., \& Cruickshank, A. A. (2007). Minimum Wage Effects on Educational Enrolments in New Zealand. Economics of Education Review, 26, 574-587.

Rice, P. (2010). Minimum Wage and Schooling: Evidence from the UK's Introduction of a National Minimum Wage. SERC Discussion Paper, 50.

Souza, P. R., \& Baltar, P. E. (1979). Salário Mínimo e Taxa de Salários no Brasil.

Suryahadi, A., Widyanti, W., Perwira, D., \& Sumarto, S. (2003). Minimum Wage Policy and its Impact on Employment in the Urban Formal Sector. Bulletin of Indonesian Economic Studies, 39, 29-50.

Train, K. E. (2009). Discrete Choice Methods with Simulation. Cambridge University Press.

Widarti, D. (2006). Role of Minimum Wage in Informal Wage Determination in Indonesia. ILO.

Wongsangaroonsri, P. (2016). The Implications of Minimum Wage Policy on School Enrolment: An Empirical Analysis of Indonesia (Thesis). 
This page is intentionally left blank 